\title{
PRELÚDIOS LITERÁRIOS DE LIMA BARRETO (1881-1922)
}

Literary Preludes of Lima Barreto (1881-1922) 


\title{
RESUMO
}

O presente artigo tem o objetivo de analisar textos pouco conhecidos e até inéditos do escritor Afonso Henriques de Lima Barreto. Por meio de pesquisas nos arquivos da Fundação Biblioteca Nacional, foi possível encontrar manuscritos nos quais o autor remete a episódios que fizeram parte da sua formação intelectual e crônicas assinadas com os pseudônimos de Philéas Fogg e S. Holmes que circularam na revista Fon-Fon, órgão de destaque na imprensa carioca do começo do século XX. Desse modo, busca-se aqui também compreender as implicações históricas das polêmicas entre os intelectuais da Belle Époque tropical.

\section{PALAVRAS-CHAVE}

Lima Barreto. História dos intelectuais. Modernismo.

\begin{abstract}
This article aims to analyze little-known and even unpublished texts of the Brazilian writer Afonso Henriques de Lima Barreto. Through research in the archives of the Fundação Biblioteca Nacional, it was possible to find manuscripts in which the author refers to episodes that were part of his intellectual formation and chronicles signed with the pseudonyms Philéas Fogg and S. Holmes in the Fon-Fon magazine, an important publication in the Carioca press in the early twentieth century. Thus, we also seek to understand the historical implications of the polemic issues among the intellectuals of the Tropical Belle Époque.
\end{abstract}

\section{KEYWORDS}

Lima Barreto. Intellectual history. Modernism. 
$\mathbf{U}$ m cânone costuma ser revisitado diversas vezes. Ao longo dessas incursões, pesquisadores podem trazer à tona aspectos pouco discutidos das ideias de um escritor ou inserir a análise de suas obras em uma série documental mais ampla. No que diz respeito a Lima Barreto, o conjunto de suas obras até então tornado público atendeu ao interesse editorial, que visou consolidar a imagem pronta e acabada do literato completamente desajustado ou injustiçado. Porém, um olhar mais demorado em torno de leituras e textos desse autor, antes da imagem do grande maldito ter sido consolidada, é fundamental para reflexões sobre as várias fases do processo de formação intelectual do carioca Afonso Henriques.

Recorro aqui a um aporte fundamentado no diálogo entre a história dos livros e das ideias. Robert Darnton esclarece que esses campos podem ser relacionados na medida em que têm a finalidade comum de "entender como as ideias eram transmitidas por vias impressas e como o contato com a palavra impressa afetou o pensamento e comportamento da humanidade" (1990, p. 109). De acordo com o historiador norte-americano, investigar fontes impressas não faz muito sentido se elas não forem articuladas com as chamadas materialidades da escrita e as práticas de leitura exercidas por atores sociais concretos.

Assim, a história dos livros não abrange apenas a confecção das obras literárias. É uma área voltada também à pesquisa dos processos de editoração desses textos e dos estágios da leitura. Em linhas gerais, essas reflexões interessam aqui porque estimulam a compreensão de "como a palavra impressa moldou as tentativas dos homens de compreender a condição humana" (DARNTON, 1990, p. 130).

Gostaria de dar continuidade a este artigo abordando o teor de um manuscrito de Lima Barreto que não consta entre os volumes que constituem as obras completas do autor lançadas pela Editora Brasiliense, em 1956. Na Seção de Manuscritos da Fundação Biblioteca Nacional, é possível encontrar um breve texto intitulado "O peso da ciência". Esse conto se encontra no verso de um documento da Secretaria de Guerra, o que atesta que o escritor exercitava o labor literário na repartição pública, na qual era amanuense, como válvula de escape para o tédio e os problemas pessoais. ${ }^{1}$

Essas anotações não foram elaboradas para serem publicadas ou se tornarem pósteras, dado o caráter inacabado e experimental do manuscrito. Nelas, o escritor carioca fez uma digressão para recordar os tempos de estudante:

De todos os meus professores - e os tive muitos - só dois deixaram sob minha alma uma impressão indelével. A minha professora primária. Uma moça clara, de olhos azuis, de quem emprestei alguma timidez e o meu professor de história universal. Os dois juntos, nas minhas impressões de meninice, se completam, entretanto as suas figuras vivas são disparatadas. Era meu professor de história um preto, um negro, diga-se, alto, magro, picado de bexigas. Tinha de tal forma a pele negra, que

\footnotetext{
${ }^{1}$ No Diário íntimo, o escritor carioca deixou diversos registros da atmosfera opressora que pairava em seu ambiente de trabalho. Porém, mais do que os preconceitos ou a empáfia dos oficiais do Exército que por lá desfilavam, o que mais aborrecia o autor era ter suas aspirações artísticas menosprezadas pelos colegas de repartição. Em uma nota de 31 de janeiro de 1905, grafou o seguinte: "Agita-me a vontade de escrever já, mas nessa secretaria de filisteus, em que me debocham por causa de minha pretensão literária, não me animo a fazê-lo" (Cf. BARRETO, 1956b, p. 97).
} 
o apuro da sua roupa branca e o asseio de seu corpo, mais realçavam a sua cor lustrosa. De mais, uma dor contida dá-lhe ao semblante um não sei o quê de doido que instintivamente me levou a simpatizar com ele (BARRETO, [19--], p. 1).

O autor acentua o caráter excêntrico desse historiador ao descrever os agasalhos que usava, mesmo "com um grande sol alto, quente e olímpico" no céu. Sua metodologia de ensino é assim narrada: "Antes de começar a lição citava um caso, embrulhava com reminiscência sua, e acabava pessimisticamente com remarques à República, ao Brasil, às suas coisas e aos seus homens". Desse modo, "pela quarta ou quinta lição", Lima Barreto ficou fascinado por esse professor. Segundo o narrador, "tratava-se da divisão de raça" (BARRETO, 19--, p. 2). Pareceu-me ser, portanto, um texto emblemático desse literato para constar em uma reflexão sobre sua formação como homem de letras.

Além de ferir dolorosamente a tecla do racismo, essa narrativa é um reconhecimento da dívida do escritor com alguns dos sujeitos que fizeram parte do seu letramento. Carrega também o sinal do típico estilo, tão marcado por essa forma de lucidez crítica e sombria, que tanto caracteriza a escrita barretiana.

O processo de maturação intelectual de Lima Barreto não foi linear ou livre de contradições. Não são poucas, porém, as referências em seus diários, artigos, contos, romances e correspondências ao universo dos impressos. Privilegiando a análise desse aspecto de sua trajetória histórica, espero evitar enquadramentos como o do sociólogo Machado Neto (1973, p. 45-49), que, em nome do "juramento de neutralidade axiológica da ciência a que ela está presa", afirmou:

O comportamento social dos intelectuais permitiria diversos modos de classificá-los. Aqui reduziremos essa gama ao mais essencial, distinguindo entre os bem-comportados, bons pais de família e incansáveis trabalhadores, e, do outro lado, os boêmios. Esses, por sua vez, poderiam ser subdivididos conforme integrassem o grupo maldito dos boêmios marginais, pobres, ébrios, caspentos, tal um Lima Barreto.

Escrito na década de 1970, o trabalho de Machado Neto reproduz, de modo conservador, alguns dos rótulos que projetaram uma imagem negativa do ator histórico Lima Barreto como álibi para que sua produção artística fosse assim também desprezada. A pecha de boêmio foi uma das principais estratégias usadas pelos altos medalhões das letras do Rio de Janeiro para não reconhecer os méritos da ficção e da atuação barretiana no panorama intelectual da Belle Époque carioca (Cf. FREIRE, 2005). Um bom método para evitar essa perspectiva reducionista sobre as singularidades de Lima Barreto é analisar sua relação com os impressos e seus intermediadores nos quadros da Primeira República.

O historiador Francisco de Assis Barbosa, em sua criteriosa biografia sobre Lima Barreto, sugere que, por ter sido oriundo de uma família modesta e negra, mas familiarizada com as letras - o pai, João Henriques, era tipógrafo do jornal monarquista Tribuna Livre, e a mãe, Amália Augusta, era professora de português -, Lima Barreto foi bastante incentivado no ambiente doméstico a se dedicar aos estudos (BARBOSA, 1959, p. 59-103). 
O diário do escritor, editado e publicado depois de muita resistência por parte de um dos organizadores da coleção "Obras completas de Lima Barreto", 2 pode ser lido como uma fonte preciosa que trata não apenas dos seus dramas íntimos, mas também de seu processo de letramento e aprendizado em torno do emprego adequado dos signos que compõem a linguagem literária. Quando começa a escrever seu diário, em 1900, com 19 anos, após ter passado por uma série de estudos preparatórios em internatos e morando em pensionatos, exercita sua linguagem literária com base na observação das conversas e dos comportamentos dos colegas da Escola Politécnica. Assim descreve as rodas de conversa formadas pelos estudantes da instituição:

Os positivistas são inflexíveis. Contrapõem, à dialética dos metafísicos, algumas fórmulas esotéricas da doutrina, e declamam contra a anarquia mental e os sofistas antissociais. Há porém os euclidianos ortodoxos, positivistas ou não, que, por vezes, se opõem com vantagem aos paradoxos impetuosos.

Quando se contempla-iluminados pelo sol vitorioso de março, que esbraseia as telhas do edifício e vem dar, aos descorados arbustos do jardinzito do pátio, um beijo escaldante de vida - quando se contempla aquela porção de rapazes, cujas inteligências moças ainda, no indivíduo e na raça, surge-nos aquela quadra espiritual da Europa pelo XII século, quando chegou às suas universidades a Enciclopédia de Aristóteles traduzida. As palavras com que Taine nos dá esse quadro remoto, poderiam ser empregadas para descrever esse contemporâneo. É com a mesma sofreguidão, é com a mesma teima sombria, é com o mesmo tropel bárbaro que aqueles moços invadem, tomam de assalto, e varam as muralhas das difíceis abstrações e das fugitivas filigranas da metafísica europeia. Talvez, no XII século, daquele trabalho encarniçado, nenhuma ideia nova se venha juntar ao patrimônio humano (BARRETO, 1956b, p. 29-30).

É interessante perceber como o escritor vai burilando seu estilo ao longo do diário. Nas primeiras anotações, recorre ao uso de um fraseado mais preciosista. Com o passar dos anos, começa a se valer da técnica de escrever de modo mais coloquial e acessível, que tanto lhe é cara. Aqui é importante destacar que o então jovem escritor frequentou um círculo bem constituído de positivistas que debatiam o pensamento de Comte com fervor. Como salienta a historiadora Emília Viotti da Costa, na época, as ideias desse filósofo francês foram amplamente divulgadas, mas a influência do "Apostolado Positivista" na sociedade carioca teve uma dimensão restrita.

Um dos leitores mais assíduos do pensador frâncico foi Licínio Atanásio Cardoso, matemático e lente da Escola Politécnica. Existiam também "muitos positivistas mais ou menos heterodoxos, como Silva Jardim ou Benjamin Constant" (COSTA, 1999, p. 416). Toda essa geração se mostrou fascinada "pela ação dos grandes homens" e "pelo culto dos heróis" (COSTA, 1999, p. 416-417).

\footnotetext{
${ }^{2} \mathrm{Na}$ "Nota prévia" que abre o Diário íntimo de Lima Barreto, publicado pela Editora Brasiliense em 1956, Francisco de Assis Barbosa esclarece que o poeta A. J. Pereira da Silva, quando começou a ler o teor das memórias do literato carioca, recuou sobre a decisão de publicar os manuscritos. Barbosa tomou então à frente do projeto e optou pela impressão dessas memórias.
} 
Ao que tudo indica, os dogmas ideológicos dessa doutrina, travestidos de científicos, foram logo percebidos pelo literato, e tal fato motivou seu gradual afastamento dessa corrente de ideias. Além do gosto pelos debates filosóficos, a música parece ter sido também uma paixão nutrida pelo estudante Afonso. Em $1^{\circ}$ de dezembro de 1900, ele publica a crônica "Francisco Braga: concertos sinfônicos" no periódico independente $A$ Lanterna. Esse jornal foi fundado por estudantes da Escola Politécnica, entre os quais Júlio Albuquerque e Bastos Tigre. Típico texto de jornalismo cultural, esse escrito coloca o leitor em face de um Lima Barreto jovem, mas bem atento aos bastidores da cultura chamada convencionalmente de erudita:

\begin{abstract}
Vimos domingo último, pela centésima vez, um magnífico e interessante concerto sinfônico, tendo um auditório ínfimo para esta cidade de oitocentos mil habitantes [...]. Um programa inteligente e de gosto, o desse primeiro concerto. Peças sinfônicas dos grandes Beethoven, Mozart e Liszt, ainda não ouvidas entre nós, aumentavam o atrativo da primeira audição de Marabá, Cauchemar, Pro Patria e do Episódio sinfônico, quatro excelentes páginas do aclamado sinfonista brasileiro. [...] Eis o característico notável da música de F. Braga: harmonia rica, brilhante; melodia sóbria, leve, tímida, sem arroubos, perfeitamente ao gosto da escola francesa (BARRETO, 2004, p. 59-60).
\end{abstract}

Lima Barreto foi atraído ainda, durante essa fase de sua vida, pela figura enigmática de um místico mineiro, descendente de islandeses, chamado Magnus Sondahl. O pensamento ecumênico desse teólogo englobava elementos de maçonaria, positivismo, catolicismo e até uma pitada de anarquismo. Nas memórias do historiador Luís Edmundo, ele é descrito, de forma aspérrima, como um sujeito "longo, feio, que usa pince-nez de cordão [...] e de quem se diz que pratica o nudismo e o amor livre nas praias ermas da cidade, longe da vista da polícia" (2003, p. 445). De acordo com o autor de O Rio de Janeiro de meu tempo, Magnus estava sempre a discutir "Hermetismo, o Ocultismo da Índia, o Cabalismo egípcio, o Esoterismo, a teosofia Ocidental e até o Mefistofelismo" (EDMUNDO, 2003, p. 445) pelas livrarias cariocas.

Criador de uma religião chamada ortologia, Sondahl recebe uma carta não datada - mas que possivelmente foi escrita em 15 de março de 1903 - de Lima Barreto, na qual o literato afirma que

tendo lido o seu catecismo ortológico e me arrastando o espírito para o estudo da ortologia, tomo a liberdade por intermédio desta perdir-vos [sic] que, se não vos é impossível, o favor de remeter-me algumas mais publicações, que esclareça o meu espírito e que também contribuam para a minha completa iniciação na ortologia (BARRETO, 1956a, p. 36).

A missiva foi assinada pelo escritor carioca com o pseudônimo de Afonso Mem de Muniz e remetida da Ilha do Governador.

O místico Sondahl pode ser compreendido como um tributário do decadentismo finissecular na Belle Époque carioca. Esses intelectuais assumiram uma grande dívida com as ideias estéticas e o dandismo do poeta francês Baudelaire. Ser um dândi não 
era questão apenas de circular pelas ruas bem-vestido, mas também de ostentar uma postura refinada, aristocrática e contestadora em relação à moralidade difundida pelo "século do trabalho" fabril.

Como salienta Marcus Salgado, em A vida vertiginosa dos signos: recepção do idioleto decadista na Belle Époque tropical, a trajetória biográfica de Huysmans, autor de Às avessas, se torna bastante emblemática para brasileiros como Elysio de Carvalho, João do Rio e Medeiros e Albuquerque. O escritor francês passou a viver como monge em 1900. A indiferença dos setores oficiais da Igreja Católica francesa diante da adesão do autor de Às avessas e de Verlaine aos seus dogmas pode ser interpretada como um sinal de que esses literatos aderiram ao cristianismo de um modo nada ortodoxo (Cf. SALGADO, 2006).

O misticismo foi um fenômeno intelectual muito peculiar da mentalidade do fin-de-siécle com fortes ramificações na Belle Époque. Assim, apesar dos apodos de Luís Edmundo, o fascínio que homens como Sondahl exerceram entre jovens aspirantes ao mundo das letras, como Afonso Henriques, merece ser mais investigado.

Sondahl envia, como resposta, uma carta atenciosa para Lima Barreto, datada de 17 de março de 1903. Resume sistematicamente os principais aspectos de sua doutrina, pautada em uma "reforma intelectual" como "a base, sine qua non, da remodelação social”. Essa sociedade ortológica, almejando atingir o uso lógico e verdadeiro da razão, instituiria uma "Plutometria" ou "medida justa de Produção e do Consumo" (SONDAHL apud BARRETO, 1956a, p. 38).

O pensamento de Magnus Sondahl se aproxima um pouco do anarquismo ao propor a "extinção do direito e privilégio imoral da 'emissão fictícia' [do dinheiro oficial]. Cada um deve ter a liberdade e a faculdade de emitir sobre aquilo que possui e aquilo que produzir" (SONDAHL apud BARRETO, 1956a, p. 38). Para realizar essa empreitada, propõe que seus simpatizantes fundem "Arcontados" locais, em oposição às "maltas e patuléias [sic] políticas e eleitorais", buscando exercer cargos influentes "no comércio e na indústria" (SONDAHL apud BARRETO, 1956a, p. 38).

Lima Barreto, ao assinar essa troca de correspondência com um pseudônimo, talvez estivesse mais curioso a respeito das ideias de Sondahl do que entusiasmado com elas. O começo da década de 1900 foi um período de estudos intensos para o literato, bem como de fortalecimento de laços com os confrades com os quais tinha mais afinidade. Foi uma época marcada também pelas suas colaborações com impressos, que, atualmente, se tornam obscuras para pesquisadores que desejam travar contato com esses textos em razão das dificuldades de encontrar tais fontes. Além de A Lanterna, Lima Barreto escreveu textos, muitos dos quais assinados com nomes fictícios, para A Quinzena Alegre, Tagarela, O Diabo e a Revista da Época.

Sobre a Revista da Época, o autor de Numa e a ninfa conheceu Carlos Viana, o editor do periódico, nos tempos em que eram alunos da Escola Politécnica. Infelizmente, os exemplares dessa publicação que se encontram nos arquivos da Fundação Biblioteca Nacional estão muito deteriorados pela ação do tempo e desfalcados da colaboração de Lima Barreto. A principal característica da publicação era tecer louvores aos mandarins da política republicana. Adotando essa estratégia, Viana conseguia levantar fundos para manter seus negócios e cavar empregos. Chegou a se tornar representante do governo brasileiro na Europa.

Para os leitores mais acostumados com as críticas frequentes feitas por Lima Barreto aos desfechos das reformas urbanas, constatar que, no começo da carreira, ele teve o nome associado a um impresso que fazia uma apologética dessa 
empreitada é algo até inusitado. Em carta enviada por Lima Barreto para Carlos Viana, em 1904, todavia, já se pode notar a incompatibilidade entre os propósitos dos dois atores históricos:

Vou precipitar a narração, pois já me invade a preguiça, e o Balzac (Lys dans la vallée) espera amorosamente os meus olhos sôfregos. [...] Não sou teu empregado, não recebo ordenado, portanto coisa alguma me obriga a escrever artigos; mas como camarada, eu te devo falar francamente, não achas?

Retornando ao assunto: assim é que não querendo eu mais que oscilações do meu amor a esta ou aquela personagem política retardem de qualquer maneira o sucesso da tua empresa, declaro-te firmemente que não sou mais secretário do teu periódico e como tal só me cabe agradecer os inestimáveis favores que mereci da tua bondade, entre as quais se acha o de me fazeres secretário da Revista da Época (BARRETO, 1956a, p. 51).

Em seu diário, em 18 de janeiro de 1905, o próprio Lima Barreto tece afirmações contundentes, mas esclarecedoras, sobre o fundador da Revista da Época:

Vim de trem com o Viana, pai e filho, neta e irmã. É um tipo curioso de aventureiro esse Viana. Fundou um jornal, a Revista da Época, do qual, por lábias sábias, obrigou-me por três números a ser secretário, do que me descartei a muito custo. A revista dele é uma espécie de retratos de varões obscuros. Quando Ihe escasseiam os recursos, ele publica um número e, no dia seguinte, corre aos retratados para buscar dinheiro.

Anda agora de gorro com um russo. Curioso vagabundo que busca fortuna. Saltou no cais Pharoux, arranjou um título universitário, é doutor, assim como, se saltasse na gare de Orléans, seria conde ou marquês (BARRETO, 1956b, p. 88).

Em uma breve epístola enviada para Lima Barreto, não datada, mas que se deduz que seja de 1908, Viana fornece os indícios de que essa descrição barretiana sobre seu caráter arrivista não é tão exagerada assim:

Hoje, peço-te que escrevas três ou quatro linguados a respeito do nosso portenhoso Nilo Pessanha e umas cinco tiras sobre o Marechal Hermes.

Além disso, se estiveres de maré faze uma crônica alegre sobre as festas de 15 de novembro, fazendo umas considerações amáveis acerca do prazer da novidade que nos trazem os quinzes de novembro de quatro em quatro anos.

Até logo.

Um abraço do teu, Carlos (VIANA apud BARRETO, 1956a, p. 53).

Não foi encontrada nenhuma resposta na documentação dos arquivos consultados nem pistas, na bibliografia especializada sobre a literatura barretiana, 
de que o escritor carioca tenha aceitado tal proposta. Entretanto, a edição de O Paiz ${ }^{3}$ datada de 13 de agosto de 1908 traz, na seção "Notas diversas", a seguinte notícia:

Está publicado o primeiro número da "Exposição Nacional", edição especial da Revista da Época, dirigida por Carlos Viana e Lima Barreto, com a colaboração fotográfica de Augusto Malta.

Tem na capa uma série de aspectos e "instantâneos" da exposição e nas páginas interiores, além de um texto interessante, várias fotografias dos edifícios do grande certâmen e retratos dos Drs. Sampaio Correia e Arlindo Fragoso, delegado da Bahia.

Miliano Palhares assina um bom trabalho sobre a Carta Régia que abriu os portos do Brasil às nações amigas (O PAIZ, 1908, p. 4).

A postura de Carlos Viana revela bastante sobre as ambições de muitos dos que se aventuraram no ofício de editor e jornalista na Belle Époque carioca. Quanto ao autor de Isaías Caminha, pode-se perceber que estudar sua trajetória intelectual com base em uma imagem pronta e acabada de escritor maldito é algo problemático. Seja pelo desejo imensamente humano, seja por reconhecimento ou pelas próprias dificuldades financeiras que enfrentou, a documentação aqui abordada aponta que, em algumas situações, Afonso Henriques teve que abrir mão de certas convicções mais arraigadas.

Vale mencionar também a atuação de Lima Barreto no periódico Tagarela semanário crítico, humorístico, ilustrado e de propaganda comercial, em 1903, sob a direção de Peres Júnior e propriedade de Raul Pederneiras. Na primeira edição, o folheto ressalta, bem na capa, que conta com "colaboração variada e escolhida", como a dos desenhistas "Raul, Falstaff, Calixto e outros conhecidos artistas" (p. 1). No editorial do primeiro exemplar, datado de $1^{\circ}$ de março de 1902 , um texto anônimo tenta transmitir entusiasmo aos leitores: "A apatia lavra nosso povo e o nosso pobre povo precisa rir, rir às escancaras: e um quarto de hora de bom humor, disfarça ou minora toda essa carrancuda máscara de todos os dias, cheia de vicissitudes e mágoas" (p. 2).

O Tagarela era um jornal de diagramação modesta, repleto de caricaturas que representavam personalidades de destaque na política brasileira da época e anúncios dos mais diversos, desde cigarros até elixires. Os sonetos e os artiguetes, assinados por pseudônimos, disputavam a visibilidade com ilustrações que tinham um posto fundamental no semanário.

Como sugere Carmem Lúcia de Figueiredo (1995, p. 39-40), as imagens que abundavam nessas revistas e nesses folhetos independentes tinham uma finalidade crítica muito marcante:

\footnotetext{
${ }^{3}$ O jornal O Paiz foi fundado na cidade do Rio de Janeiro em 1884 e fechado em 1930. Teve como slogan a frase: "A folha de maior circulação e tiragem da América do Sul." De propriedade do imigrante português João Reis Júnior, teve redatores de grande projeção, como Rui Barbosa e Quintino Bocaiúva, o principal líder do Partido Republicano. Periódico matutino que veiculou amplamente as ideias liberais e as diretrizes do abolicionismo durante toda a duração da Primeira República, teve um fim controverso quando sua sede foi destruída por um incêndio. Cogita-se que esse incidente tenha sido intencional e motivado pelo fato de a cúpula do impresso não ter apoiado a chamada Revolução de 1930.
} 


\begin{abstract}
Pela caricatura, portanto, acentuam-se os traços do rebaixamento grotesco, transferindo a capacidade de liderança e inteligência à bruta irracionalidade animalesca. Ou, no sentido inverso, o autoritarismo a eleger a fraqueza e a submissão para compor seu séquito de vassalos.
\end{abstract}

Em Lima Barreto e o Rio de Janeiro em fragmentos, Beatriz Resende pontua que essas charges tinham como função política veicular "sátiras picantes e severas aos governantes" (1993, p. 84). Ainda de acordo com a autora, Lima Barreto publicou nesse periódico, em 1903, escritos assinados pela alcunha de Rui de Pina. No arquivo da Fundação Biblioteca Nacional, deparei com 43 exemplares do Tagarela correspondentes ao citado ano. O elenco de nomes extravagantes é vasto: "Nós Todos", "Incrédulo", "L. Senior", "Gypsi”, “Jass", "Annaiv", entre muitos outros (1903, p. 1-16). No entanto, não localizei nenhum texto que, seguramente, possa comprovar ser de autoria barretiana.

\title{
REFINAMENTOS E POLÊMICAS MODERNISTAS
}

Em História \& modernismo, Mônica Pimenta Velloso, ao discutir a consolidação das correntes modernistas não só na literatura, mas também em artes visuais, música e imprensa, salienta que os pseudônimos/heterônimos foram muito comuns entre artistas europeus, brasileiros e hispânicos desde o século XIX. Baudelaire, na França, e Gonzaga Duque, no Brasil, se valeram dessa tática para defender o trabalho dos caricaturistas, por exemplo, em seus respectivos países.

Endosso aqui a tese da autora de que é necessário substituir o confuso termo "pré-modernismo", destinado a consagrar vanguardas e intelectuais conservadores que protagonizaram a Semana de Arte Moderna, em São Paulo, pela ideia de "modernismos". Esse conceito é assim detalhado por Mônica Pimenta Velloso (2010, p. 83):

Na realidade há distintas correntes fundadoras da modernidade. A primeira delas fundamenta-se no ideal iluminista do conhecimento, devotando encanto às conquistas da racionalidade e da ciência. O futuro é a sua meta, e o rigor científico, a via para alcançá-lo. A segunda vertente retoma fundamentos românticos de tradições civilizadoras anticapitalistas. Dissidente, antiburguesa, ela traduz o mal-estar da civilização. Os simbolistas integraram esse grupo que se posicionou de maneira cética e irônica frente aos avanços do progresso. É importante entender a atuação dessa contracorrente. Basta nos reportarmos à ideia do Modernismo como um conjunto de movimentos que percorreu os séculos XIX e XX. Não se trata de uma trajetória linear apontando rumos e ideias definidos. Desde Baudelaire, a modernidade fora alvo de críticas profundas, mesclando ceticismo histórico, pessimismo e utopia. A cultura brasileira retomou em grande parte esse polo dissidente. Caricaturistas e cronistas apontaram as ambiguidades do moderno, seja em atitude de denúncia, seja recorrendo ao viés irônico e coloquial. A exclusão social do regime, o seu aspecto 
autoritário, corrupto e desumano além do mal-estar intelectual destacaram-se como os temas mais discutidos.

Em termos de contexto latino-americano, bem como na Europa, as querelas/ diatribes eram constantes, e os heterônimos ocultavam a identidade real do autor e evitavam até, em casos extremos, confrontos físicos: duelos, agressões, rusgas. Nessa perspectiva, os pseudônimos são um fenômeno comum no âmbito das práticas dos artistas, desde épocas mais remotas até o contemporâneo. Pode-se pensar, seguindo os rastros do estudo de Mônica Pimenta Velloso, em uma cultura da polêmica bem consolidada e inseparável da história global dos intelectuais. $\mathrm{O}$ uso de nomes falsos e cifrados é constante nos mais variados debates, disputas políticas e manifestações estéticas firmadas nesse campo.

Lima Barreto vivenciou, nessa época, um processo de refinamento ou educação dos sentidos, de contato com os produtos culturais consumidos pelas elites cariocas, para depois se posicionar em sua trincheira de escritor militante. Após frequentar concertos, teatros e bibliotecas, discutir ideias políticas com liberais, anarquistas e monarquistas, bem como tomar conhecimento da literatura estrangeira e nacional produzida em sua época, é que o sentimento de desajuste com os ditames do establishment vai aflorando e sendo cultivado.

O autor sofreu uma grande pressão por parte do pai, antes de este ser acometido por sérios problemas mentais, para se tornar engenheiro e receber o título de doutor. Essa aspiração naufragou quando o literato desistiu do curso após sucessivas reprovações nas disciplinas de cálculo ministradas por Licínio Cardoso e acabou prestando concurso para o modesto cargo público de amanuense na Secretaria de Guerra, em 1903 (BARBOSA, 1959, p. 103-186). ${ }^{4}$

Ainda nesse mesmo ano, o autor fez algumas anotações em uma caderneta com capa de couro, uma agenda trimestral. Essa documentação está entre seus manuscritos e foi incorporada ao Diário íntimo pelos seus editores. Nela, Lima fez um esboço de um plano de estudos individual:

Curso de filosofia feito por Afonso Henriques de Lima Barreto para Afonso Henriques de Lima Barreto, segundo artigos da Grande Encyclopédie Française du Siécle XIX, outros dicionários e livros fáceis de se obter.

O curso será feito segundo a história do pensamento filosófico, devendo cada época ser representada pela opinião dos seus mais notáveis filósofos. Na passagem de uma época para outra, constituirá o grande objetivo do curso estabelecer a ligação dos dous pensamentos, as suas modificações e o que se eliminou de um e porque essa eliminação foi feita. Dessa maneira, o curso será dividido em quatro partes:

$1^{\text {a) }}$ Filosofia geral. Modo antigo de entendê-la e modo moderno de encará-la. Definição. Divisões. Lógica. Metafísica. Teodicéia (sic). Filosofias particulares das ciências e das artes. O lugar que

\footnotetext{
${ }^{4}$ Segundo Francisco de Assis Barbosa, no capítulo "Mocidade" de A vida de Lima Barreto, as provas para o concurso de amanuense, nessa época, englobavam conhecimentos em português, francês, inglês, aritmética, álgebra, geometria, geografia, história, direito, redação oficial e caligrafia.
} 
Ihes compete. Fim da filosofia. Utilidade (2 lições).

$\left.2^{a}\right)$ Filosofia antiga.

Filosofia grega (3 lições);

Filosofia alexandrina (2 lições);

Filosofia romana (2 lições);

Pensamento antigo.

$\left.3^{a}\right)$ Filosofia da Idade Média. Filosofia árabe. Escolástica.

Pensamento medievo (4 lições).

$4^{\text {a) }}$ Filosofia moderna. Escolas. Filosofia (5 lições).

$5^{\mathrm{a})}$ Filosofia contemporânea. Sociologia. Estudo das raças.

Teorias (4 lições). Pensamento atual (1 lição).

$6^{a}$ ) Filosofia chinesa (1 lição).

$7^{\text {a) }}$ Filosofia hindu (1 lição).

$\left.8^{a}\right)$ Religiões. Crenças religiosas. Animismo. Fetichismo.

Politeísmo e monoteísmo. Panteísmo e materialismo (3 lições)

(BARRETO, 1956b, p. 35-6).

É impossível afirmar com toda a certeza se o literato realizou toda essa gama de leituras ao longo de sua breve e atribulada vida. Apesar de ser um curso geral de filosofia muito bem estruturado, condizente com o perfil de um leitor que almejava ter um entendimento universal da trajetória humana, esse plano de estudos está mais para um projeto de letramento de longa duração do que algo fácil de ser realizado de modo linear.

Lima Barreto (1956b, p. 38) postula ainda que a filosofia se aproxima do saber científico ao se valer da "abstração, da determinação, da síntese e da análise, da indução e da dedução", porém o uso da inteligência filosófica pode se apropriar de sensibilidades "que o cientista não admite, nem emprega, o sentimento, a intuição".

Pode-se conjeturar aqui, portanto, que o saber reflexivo ou crítico apresentava mais atrativos do que o conhecimento positivista para o jovem Lima Barreto. Ao longo da sua trajetória, lidar com o artesanato literário foi o meio encontrado pelo escritor para canalizar essas inquietações. A rotina de leituras complexas e os encontros, em cafés e confeitarias pelas adjacências da Avenida Central, com colegas de repartição e amigos, com os quais dividia afinidades, funcionaram como forma de esquecer seus dramas domésticos. Essa fase de sua vida foi bem marcada pela disparidade entre as duas realidades pelas quais transitava. A despeito de levar uma vida simples com a família no modesto subúrbio de Todos os Santos, o escritor conhecia bem o universo particular das rodas de conversa literárias protagonizadas pelos "elegantes" do Rio.

Em suas memórias, Luís Edmundo descreveu o ambiente do Café Papagaio, situado no centro da urbe carioca, ao lado da Confeitaria Colombo. Por volta de 1903, o local era frequentado por caricaturistas de revistas como Kosmos, Fon-Fon e Tagarela, entre os quais Calixto e Raul. Apesar de não ter citado o nome do autor de Isaías Caminha - intencionalmente - entre as novas hostes da literatura no Rio de Janeiro de seu tempo, o historiador menciona a presença do escritor entre as confrarias literárias que se firmavam naquele espaço.

De acordo com o Luís Edmundo, "eram frequentadores do café, entre outros, o Estevão de Resende, tipo belo, forte, chicoteador de mariolas, [...] o poeta Peres Júnior, Silva Marques, Navarro da Costa, Lima Barreto, [...] Figueiredo Lima e Bastos Tigre" (EDMUNDO, 2003, p. 338). Também circulavam pelo Café Papagaio Gonzaga Duque, autor do romance Mocidade morta, e o poeta Mário Pederneiras. 
Em seu diário, meditando sobre esses universos díspares, Lima Barreto desabafou: "A minha casa ainda [...] é um mosaico tétrico de dor e de tolice. [...] Meu pai, ambulante, leva a vida imerso na sua insânia. Meu irmão, furta livros e pequenos objetos para vender". Referiu-se ainda à amasia de João Henriques como uma pessoa "sem a distinção da cultura nossa, sem o refinamento que já conhecíamos" (BARRETO, 1956b, p. 41).

Ainda sobre o letramento de Lima Barreto, é interessante destacar seus esforços para adquirir impressos. A fim de poder realizar seus estudos e fundamentar melhor seus postulados, o escritor começa a angariar livros que contemplem as temáticas que desejava aprofundar. Em algumas situações, recorreu aos amigos mais abastados que estavam em viagem pela Europa para lhe trazerem impressos. É o que uma carta de julho de 1905, enviada a Mário Galvão, ${ }^{5}$ indica. O correspondente foi colega do autor de Clara dos Anjos ainda no Colégio Paula Freitas e, posteriormente, de ofício na Secretaria de Guerra.

Na missiva mencionada, Lima Ihe faz o seguinte pedido:

Tenciono fazer-te uma encomenda. Livros, sabes. Sei que vais sair de Paris até o dia 20 [...]. É para a casa Félix Alcan; e são todas as obras de Schopenhauer, traduzidas para o francês, e uma monografia sobre a filosofia do mesmo, pelo Ribot.

Nisso não há insinuações: é um modo de encher a carta. Peço-te que passes por lá e indagues o preço certo. Uma outra cousa também te peço: se vires alguma cousa interessante sobre literatura, artes, história, manda-me dizer. Aí há publicações baratas e preciosas, a esse respeito.

Quando voltares para Paris, escreve-me.

Vistes já o Louvre? As antiguidades assírias e egípcias? O escriba sentado? E o que te parece a pintura, a escultura? Um delírio - não é? [...] Já viste o Brunetiére? [...] e o Anatole France? [...] Foste à Comédie, à Opéra, aos concertos? (BARRETO, 1956a, p. 135).

Essa correspondência expõe um Lima Barreto erudito, atento às obras dos grandes expoentes do pensamento em voga na Europa e que ganharam visibilidade internacional no fim do século XIX. Sobre os livros e a influência europeia na intelectualidade brasileira, é ainda Luís Edmundo quem pode fornecer aqui uma boa caracterização desse dado histórico, ao afirmar que "no começo do século lemos bastante, lemos; pena, entretanto, que o livro, em espessa maioria, continue a nos vir, sempre, de fora. Como tudo, afinal, que nos instrui". Nesse panorama, "o prestígio do livro francês, porém, continua imoderado e incondicional” (EDMUNDO, 2003, p. 431).

As mostras de arte do Louvre eram descritas com entusiasmo por aqueles que viajaram pelo Velho Mundo e retornaram para o Rio de Janeiro com relatos sobre as últimas novidades dos países tidos como as grandes vitrines mundiais do bom gosto, da civilização. Também se tem esboçadas nessa carta as inquietações de um leitor bastante exigente e sofisticado.

\footnotetext{
${ }^{5}$ Consta também que Mário Galvão, nascido no Paraná, em 1882, atuou na imprensa como jornalista do periódico Diário do Comércio, dirigido por Mário Cataruzza, e foi um dos fundadores da Associação Brasileira de Imprensa (ABI), ao lado Gustavo Lacerda, em 1908.
} 
Na Belle Époque, mesmo em um país europeu que contava com um público leitor mais vasto, como Portugal, os livros eram considerados verdadeiros artigos de luxo. Daí a considerável circulação de revistas que abarcavam temas que iam desde reportagens, passando por poesia e artes em geral, até discussões acadêmicas e que pretendiam, inclusive, disputar o mercado com a literatura.

Semanários e jornais brasileiros copiaram esse padrão editorial. Como destaca Mônica Pimenta Velloso (2008, p. 227), periódicos cariocas, entre os quais 0 Malho, Fon-Fon e Mercúrio, traziam propagandas que exaltavam suas vantagens no tocante aos livros: "Ler revistas significava, então, gastar menos tempo e obter mais informações". Nesse contexto, o talento do jovem escritor carioca atraiu a atenção da imprensa burguesa, conforme indicam as reportagens sobre o "bota-abaixo" do governo municipal de Pereira Passos e sua atuação na Revista da Época. Sua colaboração com o Correio da Manhã inicia com uma detalhada descrição do trabalho das equipes de demolição da prefeitura e culmina em uma digressão romanesca ao passado do Rio colonial.

Vale destacar também aqui sua ligeira atuação na revista Fon-Fon. Em $A$ vida de Lima Barreto, Francisco de Assis Barbosa registra que o literato colaborou com esse impresso, no primeiro semestre de 1907, se valendo dos pseudônimos de Philéas Fogg e $\mathrm{S}$. Holmes. O primeiro é um dos personagens do romance $A$ volta ao mundo em oitenta dias, do francês Júlio Verne, descrito como econômico nas palavras e frio no comportamento. O segundo se refere ao famoso detetive criado pelo inglês Conan Doyle.

Esses breves textos, assinados por Fogg e Holmes, não aparecem na meticulosa antologia que reúne todas as crônicas do escritor carioca organizada por Beatriz Resende e Rachel Valença. Na documentação encontrada, temos a estreia de Philéas Fogg quase concomitante à do próprio semanário Fon-Fon. Em uma nota veiculada em O Paiz, em 13 de abril de 1907, para divulgar a estreia da revista, o nome do autor de Policarpo Quaresma ganha destaque em meio ao time de redatores da revista ilustrada.

Um repórter anônimo de O Paiz ressalta que o periódico Fon-Fon contava com um excelente acabamento gráfico, publicidade de prestígio e muito humor nas suas páginas. O nome de Jorge Schimidt, editor da publicação, é ovacionado, bem como o leque de jornalistas e desenhistas que a revista abarcava. Assim, "o texto e as gravuras em que andam a pena de Raul, Emílio, Calixto, Lima Barreto, Leal de Souza, o magnífico poeta revelado pelos Annaes, e outros que se escondem em reserva discreta, é excelente" (O PAIZ, 1907, p. 2).

Nesses termos, considero importante explorar esses escritos, pois sugerem que a atuação jornalística de Lima Barreto foi bastante multifacetada e que seu talento com as letras não era completamente desprezado nesse período. Em 20 de abril de 1907, na crônica-conto "Falsificações", o escritor faz um tipo de comédia sobre o suposto refinamento das novas elites ao comentar o comércio de víveres adulterados:

Por parte dos consumidores o uso de gêneros perfeitamente puros tem encontrado grande resistência. O hábito é uma segunda natureza. Toda a gente sabe disso, e também que alguns viventes, para prova desse acerto, acostumaram-se a não comer e vão passando magnificamente como se ingerissem opíparos jantares. 
Com os gêneros alimentícios, a sentença verificou-se absolutamente. Há dias, no Meyer, jantando em uma casa amiga, frequentada por certa beleza, que não descrevo, porque os mais poetas ainda não se resolveram a catalogá-la - jantando, no Meyer, dizia, a filha do dono observou:

- Papai, não gosto desse café. O Sr. por que não traz o falsificado?

É o hábito, como veem, agindo como um ditador (PHILÉAS FOGG, 1907, p. 31).

Existe uma grande tensão entre a inclinação barretiana voltada ao uso da sátira e da ironia como ferramentas de contestação do status quo e a preocupação em amortecer o poder de impacto dessas críticas, pois muitos dos leitores da FonFon integravam os quadros das elites cariocas. O deboche do narrador passa da alimentação para os símbolos de distinção ostentados pelas elites que transitavam pela Avenida Central.

Ainda sobre as falsificações:

Contudo, os artigos de luxo também o são.

Nos arredores do Rio, há um curtume de peles de cães, as quais, depois de preparadas, são mandadas para as grandes fábricas de luvas da Europa.

Pouca gente talvez saiba que boa parte do aumento de renda da Prefeitura, na gestão Passos, proveio da venda de cães apanhados pela carrocinha nas ruas. Não sabiam? Pois foi.

A tal respeito, conta-se que Mme. Z, num baile do Casino, ao ter notícia disso, desmaiou...

Pobre senhora! Imaginou que as suas luvas podiam ter sido feitas com a pele de seu totó, que desapareceu [...]. Os falsificadores são terríveis... (PHILÉAS FOGG, 1907, p. 31).

Apesar de a crônica ter circulado em um periódico vinculado à grande imprensa, supor que a administração municipal não havia poupado nem os animais domésticos abandonados em sua ânsia para obter lucros é uma refinada denúncia moral e política. O texto dividido em duas colunas ocupa uma página do periódico e divide o espaço com uma fotografia na qual duas mulheres em trajes bastante elegantes, mãe e filha, saem da igreja João Batista. Talvez uma estratégia editorial para que o leitor se debruce sobre a fotografia e não se incomode tanto com o humor ferino de Fogg.

Na edição 5 da Fon-Fon, datada de 11 de maio de 1907, Lima Barreto assinou uma crônica intitulada "O fio da linha" com o pseudônimo de S. Holmes. Antes da expressão "colocar atrás das grades" significar prender alguém, no Rio de Janeiro se usava a gíria "colocar atrás das linhas". Desse modo, o jornalista faz uma série de trocadilhos com a expressão e a desdobra em analogias com a conjuntura militar. $\mathrm{O}$ delegado poderia ser chamado de "carretel"; o xadrez, de "croché"; e o soldado de baixa patente receberia a alcunha de "fiapo". É interessante perceber como termina esse breve artigo:

É possível que os puristas lá deles protestem contra essa violenta introdução de neologismos; mas como tal gente não possui Senado nem Código Civil, o protesto não tomará importância, não passando de uma insignificante impertinência de gramáticos. 


\begin{abstract}
A sociedade que rouba, naturalmente, procurará salvaguardar-se dos perigos que, contra a sua existência, vem oferecer essa moderna descoberta policial.

Gatuno algum deixará mais em suas vestes ou em seu corpo, o furo ou orifício por onde se possa introduzir a linha policial. Vão ter corpos hermeticamente fechados...

E se à coletividade de malfeitores, o novo expediente policial vai levar essas modificações, à que só faz bem, a uma, a normal, também trará desarranjo.

No mínimo, o que poderá acontecer será o emaranhamento das linhas férreas policiais com as de telefone, de telégrafo e as de estrada de ferro, causando desarranjo ao comércio e à indústria (S. HOLMES, 1907, p. 24).
\end{abstract}

Acima da crônica barretiana, temos uma charge que fazalusão ao novo automóvel adquirido pelo governo estadual. Nesse caso, de modo muito depurado, temos uma narrativa na qual alguns dos ícones do progresso técnico da capital republicana são associados diretamente ao recrudescimento das estratégias de controle social.

\title{
CONCLUSÃO
}

Poder-se-ia dizer que, no campo intelectual brasileiro, existia uma cultura da polêmica, com suas diatribes, réplicas e tréplicas. Os confrontos literários entre diversas gerações da Academia Brasileiras de Letras foram reunidos e publicados em uma volumosa edição intitulada Duelos no serpentário, graças à insídia verbal característica desses escritores. De acordo com as análises dos críticos George Ermakoff e Alexei Bueno (2005), organizadores dessa edição,

a passagem do século XIX para o século XX no Brasil, o que poderíamos chamar de a nossa Belle-Époque, foi marcada por certos modismos literários de grande popularidade, especialmente as polêmicas, e, um pouco mais tarde, as conferências. Se ambas perseveram, em seus numerosos avatares, o que elas grandemente perderam foi a sua característica de gênero literário. [...] a polêmica nesse seu período áureo vivia como duelo de verve e de inteligência verbal, contenda virtuosística, apreciada mais pelos meios do que pelos fins, despertando uma atenção quase esportiva por parte dos leitores, o que sem dúvida, como fenômeno social, desapareceu.

Conforme já foi dito, o uso de pseudônimos pelos colaboradores das revistas ilustradas do Rio era muito comum. Ocultar o nome verdadeiro era uma tática bastante apropriada para provocar polêmicas.

Sobre as razões que levaram Lima Barreto a se desligar do corpo editorial da Fon-Fon, temos uma carta enviada pelo escritor diretamente ao fundador do periódico: 
o poeta Mário Pederneiras. ${ }^{6}$ Na missiva, datada de 20 de junho de 1907, o literato alegou o seguinte:

Não me gabo de ser lá grande escritor, muito menos que o seja para proprietários da lindíssima Cosmos; entretanto, tenho feito esforços, neste e naquele gênero, para os agradar. Fantasio, imagino, faço química, escrevo pilhérias... não há meio!

Demais, vejo que as coisas minhas não agradam, ficam à espera enquanto as de vocês nem sequer são lidas, vão logo para a composição. Não há ciúme, nem despeito, mesmo que os houvesse era justo que perdoasses esse assomo d'alma, pois que de há muito venho me resignando; entretanto, não há... [...] Induzi também que é a tua bondade que me mantém lá - o que agradeço de coração - mas que o meu orgulho não aceita (BARRETO, 1956a, p. 162-63).

Certamente, o estilo de sátira de Lima Barreto destoava bastante daquelas que eram veiculadas pela maioria dos colaboradores desse impresso. Sua dedução de que os editores submetiam seus textos a um crivo mais atencioso e silenciador não foi gratuita. As sutis denúncias sociais de Philéas Fogg e S. Holmes combinam com a ironia presente em crônicas como "Um five o'clock", típica expressão que ilustra bem o cosmopolitismo agressivo exaltado na Belle Époque tropical, assinada pelo misterioso barão de Sumaret, outro heterônimo barretiano. ${ }^{7}$

Na Fon-Fon de 20 de abril de 1907, esse autor narra quanto ficou embasbacado ao receber um "clássico bilhete de grande dama: róseo, perfumado, escrito num estilo nervoso e com a caligrafia irrepreensível das moças de alta educação!" (p. 8).

A solução encontrada pelo autor de Policarpo Quaresma para provocar polêmicas e incitar o debate sobre a função da literatura na Belle Époque carioca foi, portanto, fundar o próprio periódico, com o apoio de amigos que o acompanhavam desde a época dos internatos, da Escola Politécnica e das reuniões nos cafés. Sem recorrer a pseudônimos, Lima Barreto fundou a Floreal, pois já estava convencido da inutilidade do seu esforço de procurar ser reconhecido pela grande imprensa. No entanto, esse é outro capítulo da história intelectual do carioca Afonso Henriques.

\section{REFERÊNCIAS}

BARBOSA, Francisco de Assis. A vida de Lima Barreto (1881-1922). 2. ed. Rio de Janeiro: José Olympio, 1959.

\footnotetext{
${ }^{6}$ Além de proprietário da Fon-Fon, Mário Pederneiras foi também sócio e fundador da Kosmos e do Tagarela. ${ }^{7}$ As reformas urbanas inspiradas na Paris de Eugène Haussmann implicaram no estabelecimento também de novos hábitos na sociedade carioca, imitados de uma cultura que não era genuinamente brasileira. Questionando a eficácia desta incorporação cultural, Lima percebeu que as elites cariocas constituíam um tipo de nobreza sem costumes, tradições ou qualidades louváveis. O barão de Sumaraí adaptou seu sobrenome de origem indígena para o afrancesado Sumaret. Provavelmente, por meio deste pseudônimo, Lima estava tripudiando um dos principais defensores das diretrizes eugenistas do governo: o barão do Rio Branco.
} 
BARRETO, Lima (Barão de Sumaret). Um five o'clock. Fon-Fon, Rio de Janeiro, ano I, n. 2, abr. 1907.

BARRETO, Lima (Philéas Fogg). Falsificações. Fon-Fon, Rio de Janeiro, ano I, n. 2, abr. 1907.

BARRETO, Lima (S. Holmes). O fio da linha. Fon-Fon, Rio de Janeiro, ano I, n. 5, mai. 1907.

BARRETO, Lima. Correspondência: ativa e passiva. t. I. Prefácio de Antônio Noronha Santos. São Paulo: Brasiliense, 1956a.

BARRETO, Lima. Diário íntimo: memórias. Prefácio de Gilberto Freyre. São Paulo: Brasiliense, 1956b.

BARRETO, Lima. O peso da ciência. [S.I.: s.n.]: [19--]. (Escrito em folha de rascunho do Ministério dos Negócios da Guerra.)

BARRETO, Lima. Toda crônica. v. 1. Rio de Janeiro: Agir, 2004.

COSTA, Emília Viotti. Da Monarquia à República: momentos decisivos. 7. ed. São Paulo: Editora da Unesp, 1999.

DARNTON, Robert. O beijo de Lamourette: mídia, cultura e revolução. Tradução: Denise Bottman. São Paulo: Companhia das Letras, 1990.

EDMUNDO, Luís. O Rio de Janeiro de meu tempo. Brasília: Senado Federal, 2003.

ERMAKOFF, George; BUENO, Alexei (org.). Duelos no serpentário: uma antologia da polêmica intelectual no Brasil 1850-1950. Rio de Janeiro: G. Ermakoff Casa Editorial, 2005.

FIGUEIREDO, Carmem Lúcia Negreiros de. Lima Barreto e o fim do sonho republicano. Rio de Janeiro: Tempo Brasileiro, 1995.

FREIRE, Zélia Nolasco. Lima Barreto: imagem e linguagem. São Paulo: Annablume, 2005.

MACHADO NETO, A. L. Estrutura social da República das Letras: sociologia da vida intelectual brasileira (1870-1930). São Paulo: Edusp, 1973.

NOTAS DIVERSAS. O Paiz, Rio de Janeiro, ano XXIV, n. 8715, ago. 1908.

O PAIZ. Rio de Janeiro: ano XXIII, n. 8227, abr. 1907.

RESENDE, Beatriz. Lima Barreto e o Rio de Janeiro em fragmentos. Rio de Janeiro: Editora UFRJ, 1993. 
SALGADO, Marcus. A vida vertiginosa dos signos: recepção do idioleto decadista na Belle Époque tropical. 2006. 170 p. Dissertação (Mestrado em Letras Vernáculas) Faculdade de Letras, Universidade Federal do Rio de Janeiro, Rio de Janeiro, 2006.

TAGARELA. Rio de Janeiro: ano I, n. 1, mar. 1902.

TAGARELA. Rio de Janeiro: ano II, n. 90, nov. 1903.

VELLOSO, Mônica Pimenta. História \& modernismo. Belo Horizonte: Autêntica, 2010.

VELLOSO, Mônica Pimenta. Sensibilidades modernas: as revistas literárias e de humor no Rio da Primeira República. In: LUSTOSA, Isabel (org.). Imprensa, história e literatura. Rio de Janeiro: Edições Casa de Rui Barbosa, 2008. p. 211-230.

\section{NOTAS}

\section{AUTORIA}

Joachin Azevedo Neto. Doutor. Professor adjunto, Universidade de Pernambuco, Colegiado de História, Petrolina, PE, Brasil.

\section{ENDEREÇO PARA CORRESPONDÊNCIA}

Rodovia BR 203, Km 2, s/n, Vila Eduardo, 56328-900, Petrolina, PE, Brasil.

\section{ORIGEM DO ARTIGO}

Extraído da tese - Vida literária e desencantos: uma história da formação intelectual de Lima Barreto (1881-1922), apresentada ao Programa de Pós-graduação em História da Universidade Federal de Santa Catarina, em 2015.

\section{AGRADECIMENTOS}

Agradeço pelas contribuições de Maria de Fátima Fontes Piazza, Bernardete Ramos Flores, Denilson Botelho, Letícia Borges Nedel, Tânia Regina Oliveira Ramos e Maria Teresa Santos Cunha.

\section{FINANCIAMENTO}

Este artigo foi financiado com bolsa da Coordenação de Aperfeiçoamento de Pessoal de Nível Superior (CAPES).

\section{APROVAÇÃO DE COMITÊ DE ÉTICA EM PESQUISA \\ Não se aplica.}

\section{CONFLITO DE INTERESSES}

Não houve conflito de interesses.

\section{LICENÇA DE USO}

Este artigo está licenciado sob a Licença Creative Commons CC-BY. Com essa licença você pode compartilhar, adaptar, criar para qualquer fim, desde que atribua a autoria da obra.

\section{PUBLISHER}

Universidade Federal de Santa Catarina. Programa de Pós-Graduação em História. Portal de Periódicos UFSC. As ideias expressadas neste artigo são de responsabilidade de seus autores, não representando, necessariamente, a opinião dos editores ou da universidade. 


\section{EDITORES}

Alex Degan

Beatriz Mamigonian

Fábio Augusto Morales

Flávia Florentino Varella (Editora-chefe)

Tiago Kramer de Oliveira

Waldomiro Lourenço da Silva Júnior

\section{HISTÓRICO}

Recebido em: 2 de dezembro de 2017

Aprovado em: 21 de fevereiro de 2019

Como citar: AZEVEDO NETO, Joachin. Prelúdios literários de Lima Barreto (1881-1922). Esboços, Florianópolis, v. 26, n. 42, p. 358-377, maio/ago. 2019. 